821.163.41.09-1 Штулић Б.

https://doi.org/10.18485/kud_kp.2018.ch4

\author{
проф. др Бошко Сувајџић \\ Универзитет у Београду \\ Филолошки факултет
}

\title{
ЏОНИ И БАЛКАН - МИТ О ОДЛАСКУ
}

\author{
Rekoh sebi moj bože koliko demagogije \\ sustavno poređane u artiljerijske salve \\ koliko pokradenih misli iza kojih ne stoji \\ ništa osim mržnje sujete vlasti (,,Kad fazani lete“)
}

\section{Сажетак}

Шта је Џонију Балкан? Шта су један од другога очекивали, шта су добили, на чему се темељио њихов однос, у чему су се лако налазили, у чему се пак нису разумели? Шта је Балкан ономе који је, да би га сачувао у себи, морао да оде у Холандију?

Кључне речи: Балкан, мит, рапсодија, симулакрум, музика.

Балкан као многозначни појам, као симбол, као судбина, у епицентру је Џонијевог стваралаштва. То се, уосталом, наглашава већ у Смијуријаgи (2010), Штулићевом „аутопортрету у стиху“, својеврсној пародијско-трагичкој аутобиографији или пак осебујном „портрету уметника у младости“:

1 Студија је објављена у зборнику Rock'n'roll и књижевности, ур. Драган Бошковић, Крагујевац: ФИЛУМ 2017. 
Razlog zašto volim glazbu, ako već ne muziku,

Pošto u potonju spada gluma kiparstvo knjige

I što još ne upravo je moje skopsko rođenje

Koje je s tê strane dvojako naime božje

Makedonske narodne pjesme il bolje rečeno

Neke od njih su vrh vrhova iako su više

Vlaške odnosno rumunjske ali ni slavni izraz

Makedonska salata nije bezveze dakle to

Je prvi utjecaj drugi je moja sreća da sam

Tri godine ako ne i dulje s vojskom bio

$\mathrm{Na}$ isti način kako engleske postrojbe rabe

Za maskote životinje tako sam se i ja po

Kasarni vrzmao pa kakve to veze ima s

Glazbom reći ćete e pa u to je vrijeme na

Snazi bio isti običaj koji i dan danas

Važi bar kad ratuješ u tuđoj zemlji da skoro

Svaki mjesec održavaju priredbe najveći

Zabavljači tako sam se i ja naslušao i

Nagledao svega al najviše me je dojmio

Ples u menzi poslije objeda riječju kad uz

Zvuke ora tuce njih u zrak skoči i ko jedan

Mačem o pozornicu lupi zapravo u daske

Ga zabiju sve u izvornoj nošnji mimo toga

Dva puta godišnje ispod brijega na kojem sam

Živio s proljeća i jeseni kraj Vardara

Se održavala narodna svetkovina sajam

Uz zvuke tapana zurli i svega ostaloga;

A mi smo potezali žabice na končićima

Ili lastikama i pucali na kapisle iz

Dječjih pištolja mnogu ubavo... (Smijurijada 2010: 56 -57)

Да Џони, за разлику од других представника новоталасне сцене у бившој Југославији, уметничке корене баштини из родног тла колико и из страних утицаја могло се наслутити још од првих Азриних наступа:

Ovakav izgled, međutim, nije odgovarajuća vizualizacija Azrine muzike, koja se nekome može učiniti balkaniziranim 
stremljenjem engleskom nju-vejvu, no pomnijim slušanjem može se otkriti da se radi o koncepciji koja muzički i tekstualno vuče korijene odavde, a ne iz ritm ' $n$ ' bluza, odnosno iz stranih socijalnih okvira. Silovitost, neurotičnost i zapjenušani tekstovi Azre nisu rezultat oponašanja već prije dokaz da je MekLuanovo 'svjetsko selo' stvarnost (Vlatko Fras, Polet, Zagreb, svibanj 1978, u: Govorili su o Džoniju 2010: 5).

Шта је Џонију Балкан? Балкан је географски појам, али и историјски топос, геостратешки центар, митско извориште античке цивилизације, медитеранска зона плаветнила и сјаја, источник историје и традиције. Место на коме се укрштају и преплићу различите, а често и међусобно супротстављене историје, блистави и страшни митови, племена, језици, религије. Место лепоте и сунца.

Балкан је непристајање, неприклањање, непрестано и непредвидљиво смењивање револуција и контрареволуција, друштвених уређења и друштвених беспоредака. Балкан је простор непрестаних миграција, колонизација, ратова, тектонских поремећаја. Историја Балкана, стара и нова, повест је великог гибања и покрета становништва, сталних буна, узалудних одбрана, још узалуднијих напада, погибија, заметања, осипања, нестајања и гашења. Уопште узев, Балкан је место на коме ничу древне цивилизације, али се укрштају и актуелни геостратешки интереси светских сила и путеви глобалне политике.

У Џонијевом стваралаштву, почелна песма „Балкан“ са сингла „А шта да радим/ Балкан“ означила је корениту „премјену“, коперникански обрт, смештен у питак саунд шездесетих година и дискретну новоталасну обраду. Мало ко је у овом вишезначном тексту и необичном, страсном, источњачком вокалу наслутио темељ промишљене и доследне уметничке судбине која се ево, ту, пред нашим очима, заокружује изласком Изабраних gела Џонија Штулићу у 14 књига, у издању Платоа и Балканске партије рада (г. к.): 
Uza sve to, Štulićev je Balkan, na mikro razini, možda pomalo nategnuto i bez dodatnih komparativnih opravdanja, kao otvaranje pripovijesti koja nas zanima, s ključnim stihom ,još da imam fendera vidio bi svirke", vjerojatno usporediv s nastupom Boba Dylana na Folk festivalu u Newportu, u srpnju 1965. kad je prvi put javno uzeo u ruke električnu gitaru i zasvirao „I ain’t gonna work on Maggie's farm no more". Sevdah (ili ono što je Štulić tako nazivao kao raniji oblik akustičarske amaterske karijere) i folk (u Dylanovu slučaju) bačeni su preko palube, dok nas, s druge strane, stih koji prethodi (,brijem bradu brkove da ličim na pankrte”) smješta u trenutak koji potvrđuje ,,presvlačenje”, novu popkulturnu, novovalnu artikulaciju (,ni bendovi nisu više kao što su bili/moj se amaterski priprema da sviri”, Balkan). Koliko god da se interpretacija čini zgodnom, stvari se u Balkanu mogu protumačiti i u ironijskom, zavodničkiciničnom modelu jer prije ,pankrta” i ,fendera” dolazi „moja kita miruje a furala bi furke/lepe dekle moderne/ne padaju na zurke”, pa se zaziv Balkana u vokativu „budi mi silan i dobro mi stoj" otvara i standardnom faličkom interpretativnom repertoaru. (Дуда 2006: 8)

У којој мери и данас, заокружујући своје дело, држи до свога далеког почетка из 1980. године, показује Штулић већ тиме што свој превод Хомерове Илијаgе, први пут објављен у Београду 1995. године (прво певање у Сарајеву 1991), у издању „Комуне“2, започиње акростихом којим

2 Na ovim knjigama Džoni je radio poslednjih dvadesetak godina. Uzorak Štulićevog prevodilačkog opusa prvi put se pojavio u Sarajevu 1991. godine, kada je u časopisu „Život“ objavljen njegov prepev prvog pevanja Homerove Ilijade pod naslovom Božanska Ilijada via Homer. Koristeći nekoliko engleskih prevoda, uključujući i one nekanonske, Štulić je odlučio da Homera prepeva na svoj jezik, po svom sluhu i sopstvenoj potrebi da, u susret izvesnom nadolazećem raspadu Jugoslavije i katastrofi koja je usledila, reaktuelizuje i mapira izvorište kulture kojoj pripada; otud i akrostih koji je stavio na početak svoje Ilijade: „Balkane moj, budi mi silan i dobro mi stoj - uh naopako!“ Štulić nije doslovno prevodio Homera, već ga je prepevavao, otud i ono „via“" u naslovu (Грујичић 2010). 
се суштински враћа исходишти свога певања: „Балкане мој, буди ми силан и добро ми стој: ух, наопако!“

Bijes je tvoja pjesma zlokobniče, Akilejev inat besmrtan i strašan, Loše uspomene Ahajcima nanese, Krasnim junacima podzemlja ogadi;

A smrt i pustoš darivajući svuda, Ne da se goste ptice i psine, Eh, već da božja volja bude ispunjena.

Molim, pjevaj pjesmu od začetka,

Od prvog sukoba što zakrvavi

Jakog Agamemnona i božanska Akileja.

Baš bogovi zametnuše svađu,

Uz Divova i Letina sina, Apolona, što kugu

Drsko na vojsku baci, koseći užasno,

Iznova, val za valom, nizašto,

Misleći pritom na Atrejeva sina

I to onog što povrijedi čovjeka

Svetog Hrisa, kad ovaj do brodova siđe

Istobokih, nudeći otkup za svoju kćer,

Leš u duši, na zlatnom skeptru božji stijeg,

Ahajce ljude usrdno moleći a

Najviše upravo obojicu Atrida:

Imajte milosti Menelaje i Agamemnone, i vi ostali

Dobro naoružani Ahajci, nek vam bogovi sa Olimpa

Ostvare sječu Prijamovog grada; a onda

Barem pravog vjetra u povratku, samo,

Rado bih nazad kćer za blago,

Ostalo ne ištem, bilo vam drago.

Moćan šapat zatalasa vojsku: "Ne preziri,

Istraj, daj starcu što želi, al pokupi lovu!"

Samo Agamemnon neće protiv svoje volje,

Tako daleko nitko ne izgura bolje:

Odlazi stari, ne poteži kavgu,

Jebem li ti popovsku majku.

Uhvatim li te kraj dugačkih lađa,

Huljo, još jedared, sada ili ikada, 
Ni skeptar ni stijeg pomoći ti neće.

A što se tiče djevojke, kunem ti se,

Ostariće kod mene u Argu, daleko od domovine,

Predući vunu i grijući mi krevet.

A sad, ostavi me. Bježi dok si čitav,

Kasno nije.

Oprošteno ti je.

Џони се на овоме, дабоме, није могао зауставити. Попут муњевитог и еруптивног објављивања својих обичних, двоструких и троструких албума 80-их година прошлог века, силовит и моћан као бујица, ношен незаустављивом потребом да целокупног себе озваничи и пусти у етар, тако је и ово био мегаломански захват, посве примерен Џонијевој природи:

Izabrana dela Branimira Džonija Štulića broje 14 knjiga i oko 7000 stranica, dugačka su 43 centimetra i teška 9,8 kilograma. Od četrnaest tomova, jedanaest knjiga su prevodi uglavnom klasičnih antičkih književnih i istorijskih dela, dok se tri knjige tiču samog Štulića, njegove muzičke karijere, poetike i svetonazora. Knjige su lepe i za gledanje sadrže nekoliko stotina ilustracija koje prate ono što na stranicama piše. Prošle sedmice su objavljene u zajedničkom izdanju Džonijeve Balkanske partije rada (golih kuraca) i beogradskog izdavača Plato Books (Грујичић 2010).

Све што је у вези са Џонијем обојено је снажном друштвено-политичком аромом. Уосталом, „priča o Džoniju Štuliću u dobroj je mjeri i priča o Jugoslaviji u onih posljednjih petnaestak godina uoči njezinog ratnog raspada" (Баздуљ 2010). Одласком у Холандију, Џони се устоличио у митској историји Балкана. Нови талас је пред налетом баналности и националистичког дискурса деведесетих година поклекнуо. Баналност је победила. Лишавајући идеју музике, она је музику лишила идеје. Али је мит о Џонију остао. И у свести данашњих генерација, које нису ни биле рођене када је 
Азра свирала, он пулсира несмањеном снагом, као ритам непатворене побуне у крвотоку Балкана.

Да се разумемо - Џони је један од највећих рок аутора који су ходали овим просторима. О томе сведоче фасцинантни албуми, какви ће се тешко поновити на Балкану, не само у оквирима рок музике: Азра (1980), Сунчана сиирана улице (1981), Равно gо яна (1982), Филиірански йлочниизи (1982), Каg фазани лейе (1983) и Криво срасйање (1984). У распону од само неколико година бљеснуо је тај генијални дух. Препознали су га посвећени. На нож дочекали медиокритети. Тада одевени у рухо комунистичких идеолога и цензора, данас - како би то рекао Вук Караџић, „исто то, само мало другачије“ - у образине националних идеологија и идеолога. Свима је сметало то што нас је својом електричном Музиком, том светом дисторзијом звука, овај необични човек приближио божанском принципу. Ипак, ни Џонијева музичка свежина нити пак вербална генијалност нису биле довољне да га за његова (и нашега) живота устоличе у култ. Неопходна је била лична жртва. Уз пратеће преломне друштвене, идеолошке и политичке прилике. Мучеништво, свесно мартирство, биографска вер(с)ификација.

Као и сваки мит, мит о Џонију Штулићу базиран је на аутентичној вери, на „материјализацији немогућег“, на делотворности поруке. На уверењу у вечиту (само) обновљивост света. Ритуализован је и сакрализован, смештен у свето време некадашњег златног доба - у нашем случају осамдесете године које, особито из савремене перспективе, представљају парадигму изгубљене невиности света. Искован у ватри заноса и оданости, жртве и губитка.

Мит о Џонију Штулићу делатан је и због тврдоглавог и упорног одбијања његовог носиоца да учествује у профанизацији и банализацији своје уметничке мисије и посланства, и срећно је окончан јунаковим одласком у Холандију. Џони је упорно одбијао да учествује у новим бал- 
канским конфликтима. Енергично и силовито је заћутао. Престао да даје интервјуе и изјаве за штампу. Чак није хтео да се појави ни у документарним филмовима посвећеним новом валу, какав је иначе одличан филм Срейно guјеше Игора Мирковића, тако да је филм о феномену новог таласа суштински постао филм о феномену Џонија Штулића, који је одбио да о том феномену сведочи:

Danas, tačno trideset godina pošto je napisao Balkan i dvadeset godina pošto je prvi put napustio Balkan i nastanio se u Holandiji, o odsustvu Džonija Štulića i njegovom ,potpunom koncentrisanju na odbijanje", ispleten je čitav mit. Manje ili više prisustvovali smo izdaji načela zbog kojih je navodno krenula u rokenrol avanturu većina novotalasnih prvoboraca, ali Džoni je odbio da nam priušti to zadovoljstvo. To je i razlog što Mirković njegov slučaj naziva ,posljednjom nedovršenom pričom novog vala“ (Грујичић 2004).

На мит о Џонију несумњиво је утицала и његова лична харизма. У рок култури, Џони је један од великих рок песника-бунтовника, какав је „краљ гмизаваца у кожним панталонама“" Џим Морисон. Аналогија је изводљива: велика rock 'n' roll звезда, песник, борац против конформузма, текстописац неслућене дубине израза и невероватних прелива значења, искрен до бола и патоса, склон ексцесима разне врсте, непредвидљив и егоцентричан, један у низу великих (гу)битника и гневника, још од Дилана Томаса; борац против конвенција, који своје неприпадање потврђује највишом мером - свесном одлуком о одласку из музике/живота. Контекст је исти: политички немири, рат у Вијетнаму/Југославији, социјална декаденција, крвав распад земље. Исход очекиван. Екскомунициран је онај који је Изабран, који је талентом миропомазан као преносилац (божије) поруке. Геније је поражен, разочаран, у изгнанству, нервно сломљен.

Џони, наравно, није био сам. Естетика коју је изнедрило стваралаштво новог таласа била је естетика бунта, 
отпора, зачудности и нове социјалне ритуализације. Срачуната на то да покрене и шокира масе. Првоборци новог таласа били су визионари фасцинирани новим могућностима израза, новим просторима звука, новим технологијама. Ипак, нико од њих није досезао тако дубоко, секао тако беспоштедно, изазивао такве емоционално-психолошке потресе. Са Џонијем, једино са Џонијем оголели смо историју до крви, наднели се над понор трагедије, наслутили катарзу. Од „Балкана“ до Балканске райсоguје. Јер шта је него катарза то огољено суочавање - лишено сваког самопроцењивања и рефлесија било какве врсте - са страшним, потресним, источњачким, разарајућим звуком и истинама које су почивале негде у нама, али нам до Џонија није било дато да их чујемо нити омогућено да их развидимо?!

Pišući u martu 1982. godine o koncertu u SKC-u Kremer, između ostalog, kaže: ,Video sam uzdignute pesnice, stegnuta grla, znoj, video sam odsjaje suza, video sam teški očaj i uzvišenu sreću. Ponovo sam mogao plakati kao malo dete. Vazduh je bio gust i pun, sve se osećalo. (...) Osećalo se da to negde mora pući, da to jednom mora probiti na površinu, svuda. Bio sam duboko potresen, kao nikad ranije. Pročišćenje i olakšanje. Odahnuli smo. Suočiti se s Azrom razdrljenih grudi predstavlja jedno od najupečatljivijih, najjačih emocionalnih iskustava koje sebi možete priuštiti ovih dana. Azra nas ščepa neviđenom snagom, mrvi nam lobanju, čupa utrobu, a kičma puca i pluća prskaju. U jugoslovenskom rokenrolu nisam naišao ni na šta tako blisko smrti, i ni na šta tako puno života, kao što je Azra. Branimir Džoni Štulić ide ravno do dna. (...) Mogao sam se ugušiti... i umreti srećan."

Са Балкана је потекао и тај меки сентимент, искидани, опори, тужбалички тон, са гутањем завршних слогова и необичним трилерима. Обично се на овим просторима он именовао као севgax - реч арапског порекла која означава ljubav, ljubavnu čežnju, ljubavni plamen, zanos (Скок 1971: 227, Шкаљић 1965: 561, 562). 
И само име бенда, које свесно или подсвесно асоцира на Хајнеа, и Шантића, више је него добро угођено.
Азра
Сваког дана у заранке
султанова кћи прелепа прошета до шедрвана, где роморе беле воде.
Сваког дана у заранке млад је роб крај шедрвана, где роморе беле воде; сваког дана све је блеђи.
Једно вече принцеза му приђе, запита га брзо: Желим да знам име твоје, твој завичај, твоје племе!
А роб рече: Ја се зовем Мухамед, из Јемена сам, из племена оних, Азра, што умиру када воле. (Превео Бранимир Живојиновић)

Са Хајнеом би Штулића могло да повезује и поетичко схватање лирске поезије „у којој се преплићу различити тонови - узвишено с приземним, нежно с подругљивим“ (Глумац 1975: 39). Такође и иронија као поетички став, али и израз односа према друштено-историјској стварности песниковог доба, доба револуционарних заноса, великих разочарења, потрошених идеала (Меринг 1947: 37-38).

Шта, тачније, кога све преводи Штулић у својим Изабраним gелима? Одговор је више него знаковит: Хомера, Тукидида, Херодота, Ксенофонта, Емпедокла и Аполонија Рођанина. Bhagavad Gitu i Lao Ceovu Knjigu o Taou. И 
то му није довољно па је у своме Зборнику „рапсодирао“ повест о Александру Македонском и историју Балкана:

Štulićev „Zbornik“ je neobična balkanska Kalevala u kojoj su se, pored ostalog, našli Konstantin Porfirogenit, Ljetopis popa Dukljanina, Vasilije II Bugaroubica, narodne epske pesme, $\mathrm{Kr}$ ležine Balade, sećanja o Crnjanskom, Kad su cvetale tikve Dragoslava Mihailovića, Smrt Marka Kraljevića... U drugom delu Zbornika nalaze se dve knjige - posvete piscima koje Štulić voli i poštuje. Prva je autobiografija Miloša Crnjanskog. Štulić je, naime, uzeo piščeve Komentare uz Liriku Itake, delimično ih obradio, a zatim ih, uslovno rečeno, stihovao u heksametru. Isto je učinio i s romanom koji smatra najboljim književnim delom napisanim na našem jeziku - romanom Kad su cvetale tikve Dragoslava Mihailovića (Грујичић 2010).

Једанаеста књига Штулићевог Зборника названа је источњачки Кали Jȳ̄a, и такође је везана за историју словенског Балкана:

Poslednji pak ciklus u Kali Jugi odnosi se na najstariju istoriju slovenskog Balkana. U njemu su dati spis Konstantina Porfirogenita $O$ upravljanju carstvom, u kome se prvi put pominju istorijski Srbi i Hrvati, dva bratska i prijateljska plemena oslonjena jedno na drugo u okruženju pretećih imperija, kao i Ljetopis popa Dukljanina, posvećen prvim južnoslovenskim državama na Balkanu. Iz Hronika Konstantina Mihaila Psela, vizantijskog Plutarha iz XI veka, Štulić je priredio životopis vizantijskog cara Vasilija II Bugaroubice, koji je, pored ostalog krvavo slomio prvu, Samuilovu Jugoslaviju. Knjiga se završava prigodnim izvodom iz Njegoševog životopisa kojim se na drugačiji način osvetljava znamenita ličnost najvećeg crnogorskog vladara i vladike (Исто).

Зборник Бранимира Штулића Џонија у ствари је апокалиптична, митска, готово библијска историја Балкана. Апсурдна и самосврховита. Од Постања до Апокалипсе: 
Istorija, dakle, nije učiteljica života - ali mitska istorija, makar na trenutke, svakako jeste. Stoga autor ovih spisa priziva Homerov duh da bi nam kroz lucidnu mitsku paralelu pokazao da je ma kakvo poslovanje severno od Korkire i dalje čisto ludilo. A potom, šireći se kroz vreme i prostor u svim pravcima, Štulićeve refleksije sasvim prirodno vode do zaključka da je Balkan samo epicentar pomenutog ludila, a da je čitav svet pozornica gorkog teatra apsurda. Branimir nam Štulić, evo, ponovo pomaže da ono što se na toj pozornici zbiva posmatramo kao komediju: možda je to zaista jedini način da ostanemo zdravi, neizbodeni i svakodnevni (Пауновић, Тасић 2005).

Због чега је Балкан све актуелнији у колоплету светске политике?! Можда због тога што је универзални „свет привида“" на Балкану више него било где другде на свету чулно материјализован. Нигде симулакрум није тако мрачан, тако језиво непрозиран као на Балкану:

Свет привида изнова постаје актуелан. Још од доба оштрих спорења између Сократа (Сократес) и софиста о овом предмету, статус појма привида, како у епистемолошком тако и у естетичком смислу речи, остаје релативно нејасан у контексту промишљања различитих решења која су овај предмет увела у теоријску употребу, придавши му посебан проблемски значај. За савремене филозофе, естетичаре и теоретичаре медија, појам привида - покаткад некритички проширен на читав појавни свет - према нашим интуицијама, представља кључ диференцијације између онтолошког (технички свет медија) и онтичког (дериватни универзум виртуелних појава) приступа сагледавању реалности (Вуксановић 2007).

О урбаности Џонијевог имагинарног света, о побуни против конзервативизма и зачаурености, о отпору и непристајању на било какву нормираност и конформизам можемо се учити само на један начин. Слушајући Азру: 
Sunčana strana ulice vjerojatno je jedan od najboljih proizvoda popularne kulture (dekadentnog) socijalizma, dekadentnog u smislu stare izreke da Minervina sova leti u sumrak. Posrijedi je možda najurbaniji glazbeni proizvod socijalističkih godina, ali ne na način suvremene fetišizacije urbanog i tzv. urbane glazbe gdje se etiketa urbanosti u medijskom i/ili svakodnevnom liberalnom šik-diskurzu radije vezuje uz površnu legitimaciju autora negoli što proizlazi iz habitusa njegova proizvoda. Za razliku od onih koji svoju urbanost samo deklariraju, Štulić je svoju zaslužio u borbi, na jednak način kako su je u prvim desetljećima 20. stoljeća zaslužili modernistički autori. Urbanost u tom smislu nije postindustrijska stilska etiketa nego, doslovno, modernistički način života. Album otvara stih „kada Zagreb izranja iz sna", odnosno pjesma koja u naslovu sadrži onodobni telefonski pozivni broj za taj grad, slijedi dvadesetak iznimnih prizora iz gradskog života (dekadentnog) socijalizma, da bi, naposljetku, sve završilo „odlaskom u noć” i paranoičnim „bijegom u mrak”. Grad, ulica koja ima i svoju „sunčanu stranu”, dnevni rituali, birtije, ,diskurz noći”, kao i ,pločnici” koji će već sljedeće 1982. postati „filigranski” u naslovu novoga dvostrukog albuma, buntovništvo koje provaljuje kroz naslov trostrukog live-albuma „Ravno do dna“ (1982) ili barem „devijacija” sadržana u naslovu „Krivo srastanje” - samo su neki elementi socijalističkoga urbanog imaginarija Branimira Štulića, koji je jednako tako dvostruko artikuliran, kako prema oscilacijama unutar popularnokulturne paradigme otpor - pristajanje, tako i prema konkretnim mjestima, problemima i akterima socijalističke svakodnevice. (Дуда 2006: 2)

И читајући Џонија. Или пак оне који су читали Џонија:

Govorili su o Džoniju je knjiga koja se čita kao roman, uzbudljiv roman, kao čudan križanac bildungsromana, onoga što filmski kritičari zovu biopic, osebujne hronologije, do- 
kumentarne serije te mikroistorijske studije. Knjigu otvara rečenica Svena Semenčića objavljena u zagrebačkom „Poletu” ožujka 1977. godine: „Svakako treba istaknuti i grupu Azra koja svira u standardnoj postavi - bas, bubnjevi i dvije gitare - ali koja ima zaista realne šanse za uspjeh, zahvaljujući tome što izvodi isključivo vlastite, vrlo zanimljive i specifične kompozicije.“ Zatvara je nekoliko članaka iz 2005. godine, a koji su recenzije i reakcije na prvo izdanje Štulićeve Smijurije u mjerama, koju je tog ljeta objavilo „Vreme“. Između je nekoliko stotina tekstova koji pričaju priču o Džoniju Štuliću, njegovom životu i radu. (Kad se govori o Štuliću, ne smije se reći - karijera!) (Баздуљ 2010).

Када говоримо о Џонију, морамо стално имати на уму да смо победили од себе бољега, као што је то Марко Краљевић учинио у епској поезији, коју Штулић тако издашно цитира. Имамо ли снаге да то признамо себи и тако од пораза начинимо своју победу?! И, можда, још, успемо да спасемо своју душу.

\section{Литература:}

Aзpa: Branimir Džoni Štulić, Azra: pjevane pjesme, Beograd: Плато Books: Balkanska partija rada (g. k.), 2010.

Баздуљ 2010: Muharem Bazdulj, „Glas iz centra sveta”, Vreme, br. 1036, 11. novembar 2010.

Вуксановић 2007: Divna Vuksanović, Filozofija medija ontologija, estetika, kritika, Beograd: Čigoja štampa.

Govorili su o Džoniju: Branimir Džoni Štulić, Govorili su o Džoniju: itinerer, Beograd: Плато Books: Balkanska partija rada (g. k.), 2010

Глумац 1975: Слободан Глумац, „Иронични песник Хајнрих Хајне“, у: Хајнрих Хајне, Све слобоgе: изабране иесме, Избор, превод, предговор и напомене Слободан Глумац, Београд: БИГЗ.

Грујичић 2004: Nebojša Grujičić, „Autobiografski zapisi Džonija Štulića”, Vreme, br. 726, 2. decembar 2004.

Грујичић 2010: Nebojša Grujičić, „5000 godina jebade”, Vreme, br. 1034, 28. oktobar 2010.

Дуда 2006: Dean Duda, „Užas je moja furka (socijalistički urbani 
imaginarij Branimira Štulića)", u: Devijacije i promašaji. Etnografija domaćeg socijalizma, ur. Lada Čale Feldman i Ines Prica, Institut za etnologiju i folkloristiku, Zagreb.

Меринг 1947: Франц Меринг, Хајнрих Хајне, Превела Ирма Лисичар, Београд: „Култура“.

Пауновић, Тасић 2005: Prof. dr Zoran Paunović, prof. dr Vladimir Tasić, „Vrlo neobična knjiga“, Vreme, br. 757, 7. jul 2005.

Скок 1971-1973: P. Skok, Etimologijski rječnik hrvatskoga ili srpskoga jezika, ur. akademici Deanović, M., Jonke, Lj. (1971-1973), Zagreb: Jugoslavenska akademija znanosti I umjetnosti.

Smijurijada: Branimir Džoni Štulić, Smijurijada: potpuno izdanje setopisa, Beograd: Плато Books: Balkanska partija rada (g. k.), 2010.

Шкаљић 1965: A. Škaljić, Turcizmi u srpskohrvatskom jeziku.

\author{
Prof. Boško Suvajdžić, PhD \\ University of Belgrade \\ Faculty of Philology
}

\title{
JOHNNY AND THE BALKAN - A MYTH OF DEPARTURE
}

\section{Summary}

What does Balkan represent to Johnny? What were they expecting of each other, what they got, on what was their relationship based on, where they easily found themselves, but in what things they did not understand each other? What is the Balkan to the one who, in order to preserve it in himself, had to go to the Netherlands?

Key words: Balkan, myth, rhapsody, simulacrum, music. 